\title{
LEAN MANAGEMENT: IT'S APPLICABILITY IN EDUCATIONAL INSTITUTIONS
}

\author{
${ }^{1}$ R. Pankajakshi \& ${ }^{2}$ S.V.Arundathi
}

\section{ABSTRACT}

Education plays a prominent role in shaping the careers of the individual. Education is an instrument of socialization and is considered as a powerful catalytic agent for social change. In order to sustain in the competitive world, educational institutions are trying hard to meet the every changing needs and requirements of the students. This in turn calls for the application of Lean management system in educational institutions in the academic and administrative related process without much guidance expected from the specialist.

The origins of Lean practices have been observed from late 19th-and early 20th-century in the area of industrial engineering. It is becoming an essential practice for people to become highly competent in order to survive and meet the needs and demands of the ever changing world. The application of Lean management in education can be observed in administrative processes (admissions, add/drop, purchasing, facilities, hiring, budgeting, etc.), and academic processes (courses and degree programs) to a limited extent.

Lean management helps in effective utilization of resources where the wastes such as time, money, talent and energy can be minimized to extent possible by making the system work systematically. Applicability of lean management in educational institutions can be seen more effective in ways of increasing employee's confidence, commitment and communication ( 3 C's) and individual's performance will increase over a period of time. This paper is purely conceptual analysis focusing on the applicability of lean management in the educational institutions.

Keywords: Lean Management, Sustain, tangible and intangible resources, waste management

\section{IINTRODUCTION}

Education has become an essential component for each and every citizen. Education is an instrument of socialization is considered as a powerful catalytic agent for social change. In order to sustain the competitive world, educational institutions are trying hard to meet the needs and requirements of the highly competitive world. Due to globalization there is free flow of goods. services and technology from one country to another country. In the today's scenario educational institutions are not only competing nationally but also internationally.

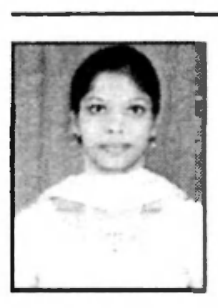

\section{${ }^{1}$ R. Pankajakshi}

Associate Professor.

Dept. of MBA, Dr. Ambedkar Institute of

Technology, Mallathahally,

Bangalore - 560056

Tel : (O): 080 23211504-6 Extn.341.

Mobile: 9844752338

pankaja_avi@yahoo.co.in
In order to provide quality education at the affordable price is taking importance and it is the responsibility of the institutions to meet the same. In this regard providing better services without any loophole is the challenging task. The working environment, attitude of the employees, students overall development can be improvised by the introduction of lean management.

(The origins of Lean practices have been observed from late 19th-and early 20th-century in the area of industrial engineering. It is becoming an essential 
practice for people to become highly competent in order to survive and meet the needs and demands of the ever changing world. This inturn calls for the application of Lean management system in an organization without much guidance expected from the specialists.)

(Lean Management application is seen essential in both the academic and administrative related activities in educational sector. The application of Lean management in education can be observed in administrative processes (admissions, add/drop, purchasing, facilities, hiring, budgeting, etc.), and academic processes (courses and degree programs) to a limited extent.)

India today is the second largest in higher education network in the world. Universities in India are set up by the Central or State Governments by means of legislation, while colleges are established by the State Governments or private bodies / trusts. All colleges are affiliated to some university.

\section{LEAN MANAGEMENT: A OVERVIEW}

The very idea of lean management is based on Just in Time (JiT), many researchers like Eli Whitney (1799), Frederick W. Taylor (1890), Frank Gilberth and Willian Gilberth has worked on this concept. Lean Management was developed by Henry Ford in 1913 followed by Kichio Toyoda, Taichi Ohno in 1930's after the world war II. This system in essence focused on the manufacturing engineer from individual machines and effective utilization. Toyota showed that by right-sizing machines for the actual volume needed, introducing self- monitoring machines to ensure quality, lining the machines up in process sequence, pioneering quick setups so each machine could make small volumes of many part numbers, and having each process step notify the previous step of its current needs for materials it would be possible to obtain low cost, high variety, high quality, and very throughput times to respond to changing customer desires

Lean management in education field is not very popular. There are very fewer instances of the adoption of this system especially in foreign countries. The educators are expected to prepare today's youth to work in the multinational companies to meet the ever changing requirements of the competitive environment with the traditional education system which was developed over a 100 years ago.

Many large Indian companies like HCL, Wipro, Tata Motors have adopted lean manufacturing principles very successfully. There are many organizations in India offering training courses and programmes in lean manufacturing. One such is the Indian Institute of Enterprise. Worldwide there are several organizations devoted to propagating lean thinking. One of the most well-known is the "Lean Enterprise Institute", USA.

\section{EDUCATIONAL INSTITUTIONS AND ITS AFFILIATION}

Education is to provide the knowledge and skills in a specialized stream in order to prepare the students to face the future challenges. This system is full of process and there is a lot of opportunity to improve the process and reduce the cost. In the current scenario, India is seen as the second largest higher education network in the world. Universities in India are set up by the Central or State Governments by means of legislation, while colleges are established by either the State Governments or private bodies / trusts. All colleges are affiliated to some university. The different types of universities are: a) Central or State Universities; b) Deemed Universities; C) Institutions of National Importance. Colleges in India come under four different categories. This categorization is done on the basis of the kind of courses offered by them (professional/vocational) / their ownership status ( Private/ Government) or their relationship with the university (affiliated/university owned).

The higher education system in India includes both private and public universities. Public universities are supported by the Government of India and the state governments, while private universities are mostly supported by various bodies and societies. Universities in India are recognized by the University Grants Commission (UGC), which draws its power from the University Grants Commission Act, 1956. [1] In addition, 15 Professional Councils are established, controlling different aspects of accreditation and coordination. 
LIST OF UNIVERSITIES IN INDIAN CONTEXT AND ITS AFFILIATION

\begin{tabular}{|c|c|c|c|c|}
\hline $\begin{array}{c}\text { SI. } \\
\text { No. }\end{array}$ & $\begin{array}{c}\text { University } \\
\text { Type }\end{array}$ & $\begin{array}{c}\text { No. of } \\
\text { Universities/ } \\
\text { Institutions }\end{array}$ & $\begin{array}{c}\text { As of Date/ } \\
\text { Month }\end{array}$ & Remarks \\
\hline 1. & Central & $42^{*}$ & June 2011 & $\begin{array}{l}\text { Established by Act of Parliament and are under the } \\
\text { purview of the Department of Higher Education in } \\
\text { the Union Human Resource Development Ministry }\end{array}$ \\
\hline 2 & State & 285 & $\begin{array}{c}30 \text { November } \\
2011\end{array}$ & $\begin{array}{l}\text { Run by the state government of each of the states } \\
\text { and territories of India, and are usually established } \\
\text { by a local legislative assembly act }\end{array}$ \\
\hline 3 & Deemed & 130 & from 23 June \\
2008 & $\begin{array}{l}\text { is a status of autonomy granted by the Department } \\
\text { of Higher Education on the advice of the UGC, } \\
\text { under Section 3 of the UGC Act }\end{array}$ \\
\hline 4 & Private & 112 & 7 June 2012 & Approved by the UGC. \\
\hline & Total & $579^{*}$ & & \\
\hline
\end{tabular}

*Note: As Central University of Jammu has not started operating as of June 2011. As of June 2012, the total number of universities in India is 567

The state with the most universities is Tamil Nadu with 55 universities. It is also the state with most deemed universities, numbering 29. Andhra Pradesh has the most state universities (32), Rajasthan the most private universities (25), while Delhi and Uttar Pradesh have four central universities each, the largest number of all the states and territories.

\section{ADVANTAGES AND DISADVANTAGES OF LEAN APPLICATION IN EDUCATION SECTOR}

Lean is a useful approach to, administrative, operational and long term improvement. The application must be well planned addressing the objectives, problems to consider, the systematic way of handing, and effective utilization of resources in order to improve the quality of the education system of the institution.

\section{ADVANTAGES OF APPLICABILITY OF LEAN MANAGEMENT:}

- Service value is enhanced due to the up gradation of quality human resources as a input to educational institutions.
- Employees are clear with the set of actions to be performed in order to achieve their institutional goals, this creates a conducive environment.

- The transparency in the use of lean management makes the process simple and its impacts can be observed in increased productivity.

- Effective utilization of human resource and equipments (tangible and intangible resources) in order to achieve the institutional goal and this in turn takes care of waste management.

- Simplified procedures will save the time and energy without costing to the resources of the institution. Time saved is timed earned.

- Enhances the quality of communication and coordination among the employees. 


\section{DISADVANTAGES OF APPLICABILITY OF LEAN MANAGEMENT :}

- Employee's resistance to change to the developments happening with the application of lean management tools in the institution.

- The very concept of understanding the importance and advantages of application of lean management in the institution is limited.

- Learning the technicalities involved in the lean process is restricted (training and development)

- High degree o standard is required to facilitate the changes.

- Unlike manufacturing sector where the quality of raw material or machinery is considered in institutions the quality of service and human resource is considered, which is quite difficult to standardize.

- Time required being stable and giving a consistent performance.

- Many of the employees are of opinion that lean leads people to change rather than allow them to improve on their own. It also forces people to come out of their comfort zone and there are chances of losing an employee in the name of adding value or eliminating the waste.

The major wastes in education system are: Time, Energy, Money and Talent.

Lean management helps in effective utilization of resources where these wastes can be minimized to extent possible by making the system work systematically.

\section{APPLICATION OF LEAN MANAGEMENT IN EDUCATIONAL INSTITUTIONS:}

Lean management applicability is seen in manufacturing sector, where it is a eye opening in service sector. Lean management basically deals with maximum utilization of available resources inturn increased customer value and minimization of waste (under utilization of man power and other related resources). In educational institute it applicability can be seen where the effective utilization of the human resources (faculties/employees) can be made in combination with technology advancements.
Lean Management will be a mighty contribution in terms of awareness and the strategy to be adopted in order to improve the quality of the teaching and the process in the institutions, with reference to the effective utilization of the grants and other limited resources in order to get the maximum benefit. Human resource management would be effective if each employee knows his/her role in the organization.

Applicability of lean management in educational institutions can be seen more effective in ways of increasing employee's confidence, commitment and communication (3C's) with the institution.

\section{CHART: APPLICABILITY OF LEAN MANAGEMENT IN EDUCATIONAL INSTITUTIONS:}

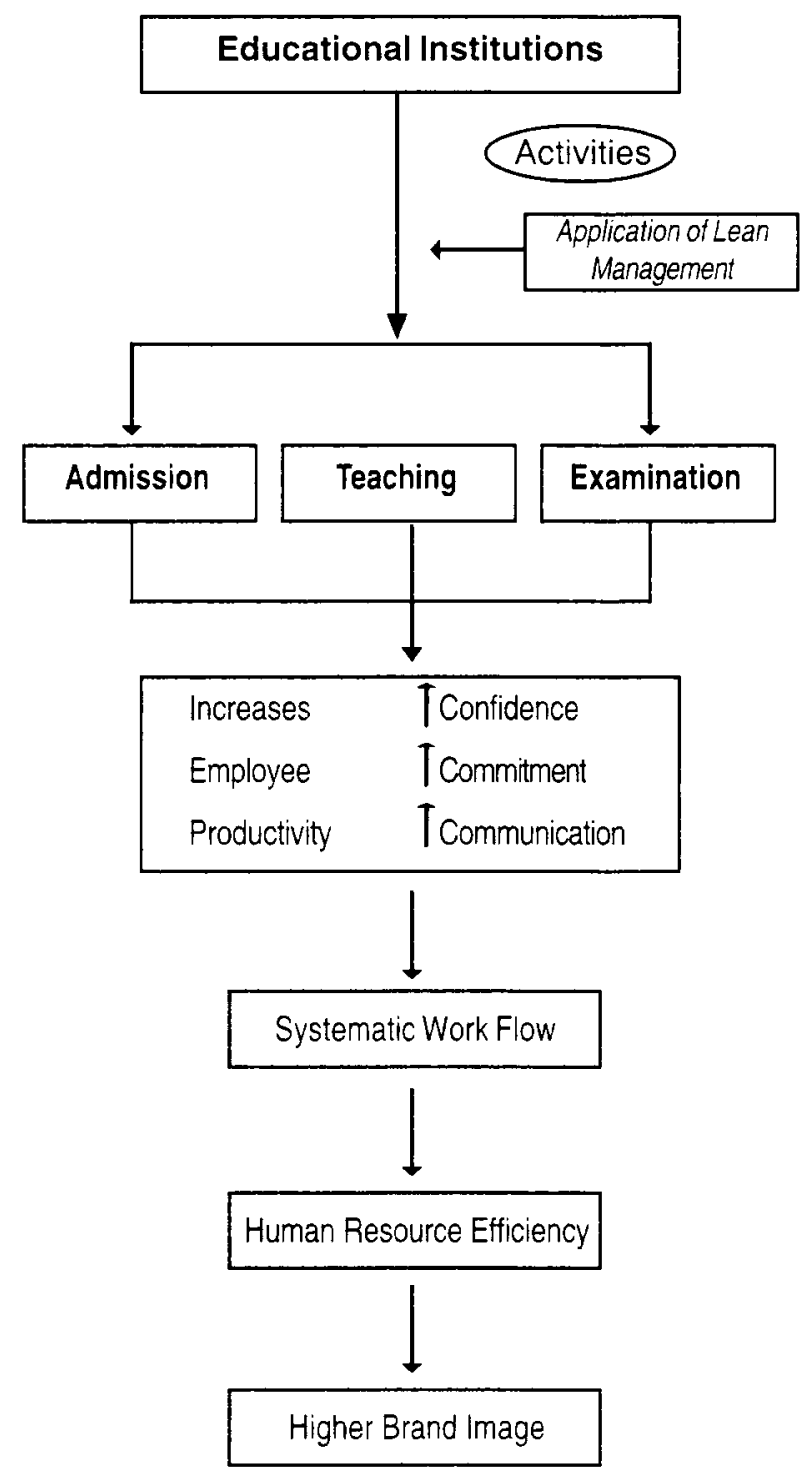

(Source: Authors) 
The above chart is self explanatory where it shows that the application of lean management in the educational institutional activities increases the employee productivity, where employee's confidence level can be raised, employees will be more committed to work and information exchange (Communication) takes place leading to systematic work setup. This in turn increases the efficiency of the employee and also creates a higher Brand image in the minds of customer/student through positive word of mouth reference.

The academic development in terms of quality and the encouragement of foreign universities in India will definitely create a huge need for the reconstruction of policies and the visions. This can lead to resistance to change. Resistance even comes from people who are chronically upset with their working environment.

"Insufficient academic skills among entry-level workers as well as inadequate abilities to work in teams can be overcome with the application of lean management in an organization/educational institutions.

\section{CONCLUSION}

The application of Lean management in any organization calls for "Continuous Improvement" leading to overall development personality of the individual in their thinking process, effective utilization of resources and at the same leads to recognition and reward of the individual. This concept can be better understand where this basically can be seen as a win-win strategy where a person is benefited in different forms at the same time the management is also found profitable.

To make lean management more effective the educational institutions need motivate the employees, take up necessary measure to ensure continuous improvement and involvement of employees, and at the same time waste reduction within the process should be given priority to become more competitive and resourceful. This will make the employees to be more professional and lessens the errors and delays; employee is enriched with skill and knowledge resulting in improved customer satisfaction.

\section{REFERENCES:}

1. Bob Emiliani (2005), "Lean in Higher Educa tion" featured article - February 2005, Copy right (C) 2005 by The CLBM, LLC.

2. Bossidy L. Ram C. (2002), "Execution: The Dis cipline of Getting Things Done", New York, Crown Business

3. Derrick Wright (2009), "The Lean Management System: Leadership Discipline" June 30, 2009, Copyright (C) 2012, Cygnus Business Media.

4. Emiliani B (2005), "Lean in Higher Education", Center for Lean Business Mangement.

5. Liker J (2004), "The Toyota Way", New York: McGraw-Hill.

6. Jeff Hajek (2009), "Overcoming Resistance to Change in a Lean Company" (c) 2009-2012 by Velaction Continuous Improvement, LLC.

7. Mann D (2005), "Creating a Lean Culture", New York: Productivity Press.

8. Michael Deese (2006), "Mastering Lean Vs. Employee Resistance: How To Bridge The Gap", Dec. 2, 2006, Visionary Products, Inc., Copyright (c) 2012, Penton Media, Inc.

9. Murman E. et.al., (2002)"Lean Enterprise Value: Insights from MIT's Lean Aerospace Initiative", New York: Palgrave.

10. "Overcoming Resistance to Change in a Lean Company" Copyright (C) 2009-2012, Velaction Continuous Improvement, LLC

11. Ross Raifsnider and Dave Kurt (2004), "Lean Six Sigma in higher education: Applying proven methodologies to improve quality, remove waste, and quantify opportunities in colleges and universities." Xerox Global Services, Inc., (c) 2004. Xerox $(\mathbb{R}$ and The Document Company $(\mathbb{2}$ are trademarks of Xerox Corporation. September, 2004

12. Wenger E., (1998), "Communities of Practice: Learning, Meaning, and Identity", Cambridge: Cambridge University Press.

13. Y.R. Parasmal (2009) "Application of Lean Thinking in Higher Education", Stratagem Consulting, India.

14. http://www.bobemiliani.com/papersforeds.html

15. http://www. superfactory.com/articles/ lean higher ed.aspx

16. http://www.citeman.com/2133-leanmanufacturing-in-india.html

17. http://www.leaneducation.com/whitepaperDoingMoreWithLess.pdf

18. http://www.velaction com/lean-information/ velaction-continous-improvement/legal

19. http://en.wikipedia.org/wiki/ list of universities in India\#cite note-6 